\title{
THE MOSQUITOES OF PUERTO RICO
}

\author{
George S. TULLOCH,
}

Division of Insects Affecting Man and Animals, Bureau of Entomology and Plant Quarantine, U. S. Department of Agriculture

\section{INTRODUCTION}

The purpose of this paper is to report the results of mosquito investigations in Puerto Rico during the period July 5, 1935, to June 1, 1936. These investigations were carried on with special funds available to the Bureau of Entomology and Plant Quarantine of the U. S. Department of Agriculture for studies on insects of P'uerto Rico. They were under the technical direction of the Division of Insects Affecting Man and Animals, and conducted in cooperation with the Federal Experiment Station at Mayagüez, where headquarters for the investigations were located. Mayagüez is situated in a region of heavy rainfall, and its proximity to the mountainous regions at Maricao and the extremely dry arid region on the southern coast made it a convenient center from which to study mosquitoes under various ecological conditions.

Puerto Rico is a mountainous tropical island. Topographically it consists of a large central mountainous region surrounded by a relatively narrow coastal plain. On the basis of variation of rainfall, the island may be divided in a general way into three regions: (1) the wet coastal plains of the north, east, and west; (2) the dry southern coastal plain, and (3) the central mountainous area, which is subject to heavy rainfall. Practically all of these regions receive their maximum precipitation late in the summer and early in the autumn (August to October) whereas the winter period (December to March) is noticably drier. The average annual temperature along the coastal region is between $75^{\circ}$ and $80^{\circ} \mathrm{F}$. Because of the influence of the surrounding ocean, seasonal and daily variation in temperature is not pronounced.

\section{Previous Work on the Mosquitoes of Puerto Rico}

In 1922 Root $(22)^{1}$ reported a list of mosquitoes that he had taken in Puerto Rico together with a summary of all previously reported species. Since that time many new species have been added (Johnson (13), Dyar (2), Wolcott (26)) and the taxonomic status of

\footnotetext{
1 The numbers in parenthesis refer to publications given in the bibliography at the end of this paper.
} 
others has been revised (Dyar (2)). The following is a list of the species which have hitherto been reported from the island with references to the papers in which the original records appeared; certain doubtful records have been omitted.

Anopheles albimanus Wiedemann (21), (12), (25).

Anopheles grabhamii Theobald (12), (25).

Anopheles vestitipennis Dyar \& Knab (13), (2).

Megarhinus portoricensis Roeder (21).

Aedes sollicitans (Walker) (26).

Aedes taeniorhynchus Wiedemann as A. portoricensis (12).

Aedes mediovittatus (Coquillett) (24).

Aedes aegypti (L.) (12), (24), (25).

Psorophora jamaicensis (Theobald) (12).

Culex quinquefasciatus Say (12), (24), (25).

Culex secutor Theobald as C. toweri (12), (2).

Culex americanus (Neveu-Lemaire) as C. bisulcatus (12).

Culex antillum-magnorum Dyar (2).

Culex nigripalpus Theobald (24) as C. simitis.

Culex atratus (Theobald) (22).

Culex habilitator Dyar \& Knab (26).

Culex inhibitator Dyar \& Knab as C. borenquini (22), (2).

Culex bahamensis Dyar \& Knab (26).

Deinocerites cancer (Theobald) (22).

Uranotaenia sapphirina Ousten-Sacken as U. socialis (22), (2).

Uranotaenia lowii Theobald (22).

Mansonia titillans Walker (26).

Wyeomyia mitchellii ? Theobald (26).

Dixa sp. probably clavulus Williston (26).

Corethrella spp. probably appendiculata Grabham (26).

The literature considered in the foregoing paragraphs has been concerned with the taxonomy of mosquitoes. There are many other papers which deal with the habits of mosquitoes and their relationships to such diseases as malaria, filaria, and dengue in Puerto Rico, and these are included along with others of a general nature in the bibliography $(1,3,4,5,6,7,8,9,10,11,14,15,16,17,18$, $19,20,21,23)$.

\section{Economic Importance of the Mosquitoes of Puerto Rico}

The geographic position of Puerto Rico is such that climatic factors are favorable for the development of mosquitoes throughout the entire year. The general mosquito problem, therefore, is of 
a greater magnitude than that of countries in temperate zones where mosquitoes are active only during a portion of the year. Not only are mosquitoes annoying to man and animals during the entire year, but many of the species transmit the causative organisms of disease.

Mosquitoes are of distinct importance because of the discomfort caused to man and animals by their bites. This is particularly true in the coastal region where the greatest concentration of population is found. The use of bed nets for protection during sleeping hours is a rather general practice, yet there are many people who, because of economic reasons, are unable to avail themselves of this means of protection. The practice of screening houses is not common and consequently practically all of the people are subjected to some degree of annoyance during their waking hours even though many of them are protected during their sleeping hours. Annoyance, then, is a general problem involving a large majority of the people. More important, from a health standpoint, however, are the consequences resulting from the transmission of eausative organisms of certain diseases of man by mosquitoes.

One of the most serious health problems which confronts Puerto $R^{\prime}$ co is malaria. The number of cleaths caused by this disease has been between 1,000 and 2,000 annually. Previous to 1924 there were few studies dealing with the incidence of this disease in Puerto Rico. In that year, however, the International Health Board of the Rockefeller Foundation initiated a study to obtain more complete information on all the phases of the malarial problem. The progress of this work has been reported in a series of publications by Earle (3-10). Among other things, these studies have indicated that malaria is a serious health problem mainly in the coastal region where the cultivation of sugarcane is the important industry, and that control of the anopheline mosquitoes is practicable in many of the regions where the incidence of malaria is high.

The distribution of filariasis has been studied by Hoffman et al. (11). Their studies indicate that this disease is, in the main, limited to the coastal region with Aguadilla on the western coast and parts of "San Juan on the northern coast as the most important endemic foci. This disease is not as important as malaria.

Prior to the American occupation of Puerto Rico, yellow fever was a common and, at times, an epidemic disease. Since the American occupation, several cases of this disease have been removed from incoming vessels to the quarantine station by public health officials. The mosquito Aedes aegypti, which transmits this disease, is very common in the coastal region of Puerto Rico. 
Dengue, although seldom fatal, is a specific fever of warm countries. Frequent cases are reported in Puerto Rico. The nature of the causative organism is not clearly understood, but it is agreed that Aedes aegypti is involved in its transmission.

\section{Methods of Collection and Identification}

Field collections of larvae were made in all situations in which stagnant or slowly moving waters were present. Most of these collections were made in the western portion of the island but frequent survey trips were made into the eastern portion. The usual situations in which larvae were collected were street gutters and eulverts, cisterns and rain barrels, drainage, roadside, and irrigation ditches, swampy areas, and along the margins of ponds, lakes, and rivers. In addition, water was taken from tree holes, crab holes, and the leaf bases of certain plants and examined. The temperature, hydrogen ion concentration, and chlorine content of waters containing larvae were determined by standard field methods. The forms were determined in the larval stage or reared and determined by adult characteristics.

Adults were taken by several methods. In order to determine the relative abundance and distribution of those mosquitoes attacking warm-blooded animals, horse traps were employed. The native horses are small so that a trap seven feet long, five feet high, and 4 feet wide is sufficient for this purpose. The small size of the trap facilities its transfer from one locality to another without difficulty. In addition, the cost of a horse suitable for this purpose is small, which further increases the desirability of the method. The procedure used was to put the horse in the trap late in the afternoon and to collect the trapped mosquitoes just before sunrise the following morning. Collection of adults by light traps was also found useful in determining abundance and distribution of various species, especially certain kinds not usually taken in horse traps. These traps were of the box type, the source of light being a 200-watt clear glass bulb. Other methods for collection of adults were collections in houses to determine the forms that enter dwellings, and net collections in the fields and woods and regions where the use of horse or light traps was impracticable.

The collections from the various sources were examined and the abundance and distribution of the species recorded. The specimens that could not be identified in the field were forwarded to the Division 
of Insect Identification for determination. This opportunity is taken to acknowledge, with thanks, the invaluable assistance rendered by Dr. Alan Stone of that division.

\section{Habits, Distribution, ${ }^{2}$ and Species of Puerto Rican Mosquitoes}

In general, the larval habitats of the various species of mosquitoes in Fuerto Rico may be grouped under the following seven type locations:

1. Stagnant water around dwellings.

(a) In cisterns and water barrels-Aedes aegypti.

(b) In tin cans, temporary pools, and street gutters (fig. 1) -Culex quinquefasciatus, Anopheles albimanus, and occasionally Culex nigripalpus.

2. Open-country breeding places (swampy areas, roadside, drainage (fig. 2), and irrigation (fig. 3) ditches, and the edges of ponds (figs. 4 and 5), lakes, streams, and rivers)-Psorophora pygmaea, P. jamaicensis, Aedes scapularis, A. taeniorhynchus, Culex pilosus, C. inhibitator, C. carcinophilus, C. atratus, C. nigripalpus, C. secutor, Uranotaenia sapphirina, U. lowii, Anopheles albimanus, A. grabhamii, Corethrella appendiculata.

3. Crab holes-Deinocerites cancer, Corethrella appendiculata.

4. Tree holes-Megarhinus portoricensis, Aedes mediovittatus, Corethrella appendiculata.

5. Leaf bases of bromeliads and other plants (fig. 6)-Wyeomyia mitchellii, Culex americanus, Megarhinus portoricensis, Corethrella appendiculata.

6. Brackish water pools-Psorophora pygmaea, Aedes sollicitans, A. taeniorhynchus, Culex inhibitator, C. bahamensis, C. nigripalpus, C. habilitator, C. atratus, Urànotaenia sp., ${ }^{3}$, Anopheles albimanus, A. grabhamii, A. crucians.

7. Atfached to roots and submerged stems of aquatic plants-Mansonia indubitans, $M$. titillans.

The following paragraphs give the species of mosquitoes collected by the writer in Puerto Rico with notes on their habits, abundance, and distribution.

1. Wyeomyia (Wyeomyia) mitchellii (Theobald).

This species is found breeding in the water contained in the leaf bases of epiphytic bromeliads in the higher altitudes of Puerto Rico.

2 The distribution records indicated by (WAH) were made available by Dr. W. A. Hoffman of the School of Tropical Medicine. Records followed by HT indicate horse-trap collections and those followed by LT indicate light-trap collections. Unless otherwise indicated in the text, the remaining records refer to larval collections.

${ }^{3}$ A third species of this genus was taken in net collections in a thickly wooded area at Mayagüez in May, 1936. It represents a new species the description of which Dr. W. A. Hoffman has in manuscript. 
The larvae are yellow in color and move about with a gliding motion over the debris in the leaf bases. The water in which they live is either slightly or distinctly acid, having a hydrogen ion concentration corresponding to a $\mathrm{pH}$ ranging between 4.0 and 6.5. The temperature of the water varies between $68^{\circ}$ and $81^{\circ} \mathrm{F}$., being lower on the higher points such as Bretton Peak in the Luquillo National Forest and higher at such points as Maricao. The adults are small bluishgreen forms which have conspicuous white markings on the hind legs. Apparently they are not attracted to horses, since none were taken in a horse trap operated on Maricao Mountain during November 1935 at a time when larvae and pupae were present in the vicinity. At times they attack man but cannot be considered fierce biters.

Other species of mosquitoes associated, with this form in bromeliads are Culex americanus, Corethrella appendiculata, and Megarhinus portoricensis.

Distribution Records: Maricao, August 15, 1935, No. $1 ;{ }^{4}$ Maricao Insular Fórest, October 28, 1935, No. 1, January 20, 1935, No. 10, May 5, 1936; Luquillo National Forest, March 24, 1936, April 12, 1936, May 21, 1936.

\section{Psorophora (Grabhamia) pygmaea Theobald.}

The larvae of this species are large, have inflated air tubes, and prefer to live in temporary fresh-water ground pools containing little or no vegetation. However, they are able to develop in brackish water, for at Lake Guánica they were found in hoof-track pools containing 665 parts of chlorine per 100,000 parts of water.

The adults are large, well marked forms which are fierce biters during both night and day. "In one case at Ponce on October 3, 1935, they were taken off white children playing in the bright sun shortly after noontime. No other observations of a similar nature were made during the investigation. - They occasionally enter houses in search of blood; and they are also attracted to animals such as horses, since they usually were present in all horse-trap collections. A few were taken in light-trap collections.

The records available indicate that this species is fairly common on the southern coast of Puerto Rico.

Distribution Records: Central Aguirre, August 15, 1935; Santa Isabel, August 15, 1935; Ponce, October 3, 1935, No. 3; Guánica, October 9, 1935, No. 8; Mayagüez, November 14, 1935.

\footnotetext{
4 Numbers following a locality and date record refer to the author's record file maintained during the course of the work.
} 


\section{Psorophora (Grabhamia) jamaicensis (Theobald).}

The larvae of this form are slightly larger than those of $P$. pygmaea. They are found in temporary surface pools and oceasionally in roadside ditches. Usually, they are the only species present in a given pool although Anopheles albimanus, Culex inhibitator, C. pilosus, and Uranotaenia lowii have been taken with it.

The adults are large and vicious biters. They were taken in large numbers in certain of the hors̃e traps, especially those along the seacoast at Mayagüez. Occasionally adults were taken in small numbers in light-trap collections.

Distribution Records: Mayagüez, August 22, 1935, August 30, 1935, September 17, 1935, No. 1, November 14, 1935, November 29, 1935, No. 1, November 30, 1935, LT.

\section{Aedes (Ochlerotatus) nubilus (Theobald).}

The larvae of this form were not found in the water taken from crab holes. Dr. Stone, however; was able to recognize the adult from collections of mosquitoes taken in the entrances to the holes. Other species in company with this form were Culex janitor, Deinocerites cancer, and Aedes taeniorhynchus.

Distribution Record: Dorado, September 1, 1935.

\section{Aedes (Ochlerotatus) tortilis (Theobald).}

This form was first recognized in horse-trap collections from Las Mesas (elevation 1,000 feet) in Mayagüez. During the period October $3-9,1935,198$ mosquitoes were taken in 7 collections and 95 percent of these were Aedes tortilis. Later (November 1935) the same species was taken in a horse trap on Maricao Mountain (elevation 3,000 feet), and during 1936 they were found in horse-trap collections in the regions along the sea coast. This species apparently prefers higher altitudes and it is suspected that this is the form that frequently annoys men working in the mountain forests of Puerto Rico.

Although an intensive search was made for the larvae not one was located.

Distribution Records: Mayagüez, August 7, 1935, HT, October 4, 1935, HT, November 14, 1935, HT, May 2, 1936, HT; Maricao Insular Forest, November 2, 1935, HT ; November 3, 1935, HT.

\section{Aedes (Taeniorhynchus) sollicitans (Walker).}

This species was taken in both the larval and adult stages at several places along the southern coastal of Puerto Rico. In no case, however, were larvae taken in coastal salt marshes, which is the usual habitat for this species. The larvae were first taken in 
hoof-track pools along the edge of Lake Guánica. Although the water in the lake is only slightly brackish (25 parts Cl. to 100,000 parts of water), the water in the small pools adjacent to it becomes concentrated by evaporation. Some of these pools have a chlorine content as high as 900 parts per 100,000 parts of water. Large numbers of larvae of this species were found in this region at various times. The presence of this species in pools having a chlorine content not greater than 900 parts is considered unusual. In the tidal marshes of the eastern coast of the United Sates this species prefers to live in pools having a high chlorine content, it oftentimes being equal to, or greater than, that of coastal sea water. Other species were found breeding in pools with sollicitans, among them Anopheles albimanus, Culex bahamensis, and C. nigripalpus. The adults are active and attack freely at night and during the day.

Distribution Records: Guánica, October 25, 1935, January 23, 1936, No. 2, May 18, 1936; Aguirre, October 30, 1935, No. 2, October 31, 1935, No. 1; Guayama, October 31, 1935, No. 5; San Juan, October 4, 1930 (WAH).

\section{Aedes (Taeniorhynchus) taeniorhynchus (Wiedemann).}

The larvae of this species are found in pools of a semipermanent or permanent nature in the coastal plain region. Apparently they do not have any particular preference for any special kind of water since they were taken in clean, dirty, fresh, and brackish pools. Other species found with them in fresh water pools were Anopheles albimanus and Culex nigripalpus. In the brackish pools at Lake Guánica $C$. bahamensis and A. albimanus were associated with this species. The adults are quite numerous in certain regions and were taken in large numbers in two of the horse traps operated near the seashore at Mayagüez.

Distribution Records: Dorado, November 7, 1935 (WAH), September 1, 1935; Guánica, October 9, 1935, No. 1, October 25, 1935, No. 1; Mayagüez, August 24, 1935, HT, September 11; 1935, No. 1, November 14, 1935, HT; San Juan, October 1932 (WAH).

\section{Aedes (Finlaya) mediovittatus (Coquillett).}

The usual larval habitat of this species is tree holes. In Puerto Rico many suitable cavities containing water are found in the native mango trees. This species is not entirely restricted to tree holes, since in one case larvae were found associated with the larvae of Aedes aegypti breeding in stone crocks which were piled edgewise in a greenhouse at Mayagüez. The presence of these two species in this situation represents an overlapping of habitats. The larvae found 
in tree holes are often associated with two species of predatory mosquito larvae, Megarhinus portoricensis and Corethrella appendiculata. The $\mathrm{pH}$ of water in these situations is usually very nearly neutral. The adults are conspicuously marked with white. They were taken in light traps in a few cases.

Distribution Records: Pueblo Viejo, August 31, 1935, No. 1; Mayagüez, September 18, 1935, No. 1, October 4, 1935, No. 2. November 7, 1935, No. 3, December 6, 1935, No. 1; Guayama, October 26, 1930 (WAH); Yauco, April 1932 (WAH).

\section{Aedes (Howardina) aegypti (Linnaeus).}

Aedes aegypti is one of the two species of mosquitoes that is nearly always found in the neighborhood of dwellings in Puerto Rico. In the poorer, thickly settled regions the rain water is saved either for drinking or washing or both. The receptacles used to collect the water, either barrels or cisterns, usually are not covered and they are therefore easily accessible to the females for depositing their eggs.

This species was taken in all parts of the coastal plains of Puerto Rico and in many of the towns high in the mountains.

The adults are fierce biters and attack freely and without warning during the day and early in the evening.

Distribution Records: Mayagüez, July 31, 1936, No. 4, August 1, 1935, No. 1, August 3, 1935, No. 1, August 22, 1935, No. 2, October 21, 1935, No. 1, October 21, 1935, No. 1, December 4, 1935, No. 1, February 15, 1936, No. 5, April 10, 1936, No. 2, April 9, 1936, No. 1; Rincón, August No. 4; Guánica, October 9, 1935, No. 2; Fajardo, November 13, 1935, No. 5 A; San Juan, December 19, 1935, No. 2, October 1, 1926 (WAH); Catalu, December 19, 1935, No. 4; Hormigueros, April 3, 1936, No. 1; San Germán, April 3, 1936, No. 3; Guayanilla, April 6, 1936, No. 1; Cabo Rojo, April 7, 1936, No. 1; Lajas, April 7, 1936, No. 8; Aguada, April 8, 1936, No. 3; Aguadilla, April 8, 1936, No. 7; San Sebastián, April 8, 1936, No. 10; Quebradillas, April 9, 1936, No. 4; Camuy, April Э, 1936, No. 6; Hatillo, April 9, 1936, No. 7; Arecibo, April 9, 1936, No. 8; Peñuelas, April 15, 1936, No. 1; Ponce, April 15, 1936, No. 2.

\section{Aedes (Ochlerotatus) condolescens Dyar \& Knab.}

A form suspected to be this species was taken by sweeping an area covered with dead leaves in a deeply shaded wood in Mayagüez. An examination of the male genitalia substantiated this identification. The larva is unknown.

Distribution Record: Mayagüez, May 21, 1936. 


\section{Aedes (Ochlerotatus) scapularis (Rondani).}

This species is represented by a single larva taken on the edge of a roadside ditch at Mayagüez. It was associated with Dixa sp., Corethrella appendiculata, and Uranotaenia lowii.

Distribution Record. Mayagüez, May 16, 1936, No. 1.

\section{Mansonia (Mansonia) titillans (Walker).}

Males and females of this form were taken in small numbers from the light trap at the Experiment Station in Mayagüez during the fall of 1935. No specimens were taken in horse traps, and it is not known if the females attack man or animals. The larvae were not taken.

Distribution Records: Mayagüez, September 26, 1935, LT, November 25, 1935, LT.

\section{Mansonia (Mansonia) indubitans Dyar \& Shannon.}

This species previously was known only from adults, During these investigations the larvae were taken for the first time attached to the submerged stems of Pistia stratiodes. Larvae brought into the laboratory reattached themselves to stems of Pistia and developed to maturity. A description of the larva follows:

Description of the larva of $M$. indubitans: Length 6-7 mm. Head one-fourth wider than long; antenna (fig. 7) long and slender, longer than width of head, a large hair tuft at the middle of the basal portion, terminal portion long and slender with an articulation at the distal end, two long terminal setae present arising from end of basal portion equal in length to terminal portion of antenna. Head hairs small and in multiple tufts. Lateral comb at eighth segment of eight to ten scales arranged in a single row, each scale fringed outwardly with large spines. Air tubes (fig. 8) less than twice as long as wide, the basal portion broad, a terminal portion sharply attenuated with saw-like teeth on upper edge; a pair of hair tufts on lower portion of basal portion, a single pair of hairs on upper edge of tube at junction of basal and terminal portions; pecten absent. Anal segment nearly twice as long as wide, ringed by dorsal plate and covered with fine pilose setae; dorsal tuft of many long hairs, all joined at base; lateral hair, a small tuft of long hairs; ventral brush of long hairs. Anal gills four, pointed and shorter than anal segment. (Larval and pupal skins and reared male in the collection of the United States National Museum.)

The females were taken in numbers from light and horse traps. It is not known if they enter houses in search of blood. The records given below are the first for the West Indies. 
Distribution Records: Lake Cartagena, November 16, 1935, HT, November 23, 1935, No. 5, HT; Sabana Grande, May 22, 1936, LT.

\section{Deinocerites cancer (Theobald).}

The larvae of this form develop in the water found in crab holes near the sea coast. The adults may be found resting in the mouths of crab holes during the day. Males have been taken from light traps at night, and females engorged with blood have been found in horse traps. The females have been observed also in houses at night.

Distribution Records: Dorado, September 1, 1935; Mayagüez, November 14, 1935, HT.; Central Aguirre, July 15, 1935.

\section{Culex (Mochlostyrax) pilosus Dyar \& Knab.}

The larvae of this form were taken in a roadside ditch in association with many other larvae. The larvae rest on their backs on the bottom of the pool and when disturbed exhibit a peculiar wiggling motion of the hinder parts of the body which is different from that of any other tropical Culex encountered. The larvae were fairly numerous during the latter part of November 1935 but were not encountered again until May 1936. Larvae of Uranotaenia are nearly always found associated with this species and quite frequently Anopheles albimanus and Psorophora jamaicensis were present as well.

Distribution Records: Mayagüez, November 26, 1935, No. 1, November 27, 1935, No. 3, November 29, 1935, No. 1, May 31, 1936.

\section{Culex (Mochlostyrax) inhibitator Dyar \& Knab.}

This species is one of the most abundant of the Culex group. It develops in roadside ditches, swampy areas, edges of ponds (fig. 4), and in both fresh and brackish water. In general, it is found in all types of clean water, rarely being found in water that is polluted with sewage (fig. 5). In one instance it was taken in water containing 770 parts of chlorine per 100,000 parts of water (Añasco: River).

The adults of this species were taken in a horse trap at Lake Cartagena. No other evidence relative to their blood-sucking habits is available.

Distribution Records: Mayagüez, August 21, 1935, No. 3, November 29, 1935, No. 1, December 10, 1935, No. 3, January 8, 1936, No. 1, January 10, 1936, No. 1, January 15, 1936, No. 1, March 15, 1936, No. 1; Hormigueros, September 17, 1935, No. 3 ; Guánica, October 9, 1935, No. 4; Rincón, October 10, 1935, No. 5; San Anto- 
nio, October 10, 1935, No. 1; Lake Cartagena, November 11, 1935, No. 4; Guanajibo, Mayagüez, November 7, 1935, No. 2; San Sebastián, January 17, 1936, No. 1; Dorado, February 1932, (WAH).

17. Culex (Mochlostyrax) carcinophilus Dyar \& Knab.

Only the larval stage of this species was taken. It is reputed to develop in crab holes but these specimens were taken along the edge of Lake Cartagena in water containing a large amount of floating vegetation.

Distribution Records: Lake Cartagena, November 11, 1935, November 23, 1935.

\section{Culex (Melanoconion) atratus Theobald.}

The larvae of this species were taken in pools of a more or less permanent nature containing some vegetation. They were associated with Anopheles albimanus and Uranotaenia sp.

The adults were not recognized in house, light, or horse-trap collections.

Distribution Records: Mayagüez, August 22, 1935, No. 1, October 7, 1935, No. 1, October 8, 1935, No. 2, November 7, 1935, No. 4; Dorado, February 1932 (WAH), September 1, 1935, No. 4; San Juan, April 26, 1929 (WAH).

\section{Culex (Melanoconion) americanus (Neveu-Lemaire).}

The larvae of this species were taken in the leaf bases of the following three plants: (a) The bromeliad Guzmania berteroniana: (b) "malanga", Caladium colocasia (fig. 6); and (c) a plant without any common name, Dieffenbachia sequine. The bromeliads found in the mountainous regions of Puerto Rico are the most important and most abundant of the host plants mentioned above.

The water in the leaf bases of the bromeliads in which these larvae live always is acid. In some cases larvae were taken from bromeliad water having a $\mathrm{pH}$ of 3.8. Usually, however, the pHI range is between 4 and 6 . Other mosquito larvae present in bromeliad leaf bases are Megarhinus protoricensis, Wyeomyia mitchellii, and Corethrella appendiculata.

The adults were not taken in horse-trap collections in regions where the larvae of this species were abundant, and it is assumed, from this, that they do not usually attack warm-blooded animals.

Distribution Records: Maricao, August 15, 1935, No. 1, August 25 , 1935, No. 1, October 13, 1935, No. 1, October 28, 1935, No. 1, November 7, 1935, No 1, January 28, 1936, No. 10, May 5, 1936, No. 1, May 21, 1936; Luquillo National Forest, March 24, 1936, No. 1, May 21, 1936, No. 1. 


\section{Culex (Culex) bahamensis Dyar \& Knab.}

The larvae of this species are restricted to brackish water. On one occasion the water in a large pool at Salinas appeared black because of the large number of larvae present. The larvae also were taken in the hoof-track pools along the edge of Lake Guánica in water having a chlorine range of from 195 to 900 parts per 100,000 of water. Species associated with bahamensis in brackish water pools were Aedes sollicitans. Anopheles albimanus and Culex nigripalpus.

Distribution Records: Salinas, October 31, 1935, No. 8; Guánica, January 23, 1936, No. 1; Dorado, August 15, 1930 (WAH.)

\section{Culex (Culex) habilitator Dyar \& Knab.}

The larvae of this species are able to develop in either fresh or brackish water. They were taken in large numbers from brackish pools (185 parts C1 per 100,000) along the Añasco River and in the brackish hoof-track pools at Lake Guánica. They were also taken in the swampy fresh-water areas in Mayagüez. Other larvae associated with this species were Anopheles albimanus and Uranotaenia lowii.

During the day, the adults may be found resting under dried leaves in shaded places in the forest. Their feeding habits were not determined.

Distribution Records: Mayagüez. July 27, 1935, No. 1, August 21, 1935, No. 1, May 7, 1936, No. 1; Ensenada, October 9, 1935, No. 1, October 17, 1935. No. 1; Guánica, October 9, 1935, No. 5; Dorado, October 1, 1930 (WAH).

\section{Culex (Culex) nigripalpus Theobald.}

This species is probably the most abundant of all tropical forms of Culex. It is found breeding in large numbers in the open country and in the towns, in fresh and brackish pools and in clean and sewage-polluted waters. The larvae have been found associated with Uranotaenia lowii, Corethrella appendiculata, Aedes taeniorhynchus, Anopheles albimanus, A. grabhamii, Culex quinquefasciatus, Aedes sollicitans, Anopheles crucians, and Culex bahamensis.

The adults rarely enter houses.

Distribution Records: Mayagüez, July 8, 1935, No. 1, July 25, 1935, No. 2, August 22, 1935, No. 3, August 28, 1935, No. 2, September 7, 1935, No. 1, September 9, 1935, No. 1, September 11, 1935, No. 2, September 13, 1935, No. 1, September 18, 1935, No. 2, September 29, 1935, No. 1, October 7, 1935, No. 2, December 10, 1935, No. 4, December 14, 1935, No. 2; Añasco, August 20, 1935, No. 5, August 19, 1935, No. 1, September 19, 1935, No. 3; Hormigueros, 
September 17, 1935, No. 4; Guánica. October 9, 1935, No. 6, January 23, 1936, No. 2; Ensenada, October 17, 1935, No. 1, October 25, 1935, No. 4 Las Marías, January 17, 1936, No. 2; Dorado, October 1930 (WAH).

\section{Culex (Culex) janitor Theobald.}

This form is known only from adults collected in the mouths of crab holes. Dr. Hoffman has taken the larvae in crab holes at Pue. blo Viejo.

Distribution Records: Dorado, September 1, 1935; Mayagüez, April 29, 1936, No. 3; Pueblo Viejo, November 2, 1935 (WAH).

\section{Culex (Culex) secutor Theobald.}

The larvae of this species appear to prefer water which is cool, since they are found in permanent pools at high altitudes or in deeply shaded pools in the lowlands. They were taken in the same pools with the larvae of Chaoborus brasiliensis.

Distribution Records: Mayagüez, October 17, 1935, No. 1, February 15, 1936, No. 6; Maricao, January 28, 1935, No. 9; Luquillo National Forest, April 12, 1936.

\section{Culex (Culex) quinquefasciatus Say.}

This species is probably the most abundant form found in the towns and cities of Puerto Rico. It is found around habitations in nearly all parts of Puerto Rico with the exception of certain high mountainous areas. It is able to develop in clear water or in water heavily laden with sewage. Street gutters (fig. 1), drainage ditches (fig 2), tin cans, etc., are suitable places where water may collect and breeding result. it usually does not have the association of other mosquito larvae although rarely it is found with Anopheles albimanus, Aedes aegypti, and Culex nigripalpus.

The adults enter houses in great numbers in search for blood, and from the standpoint of annoyance it is the most important species. It is probably the only mosquito vector of filariasis in Puerto Rico. This disease is of some importance on the Island.

Distribution Records: Mayagüez, July 10, 1935, No. 1, July 4. 1935, No. 1, July 11, 1935, No. 2, August 1, 1935, No. 2, August 18, 1935, No. 1, August 21, 1935, No. 4, August 27, 1935, No. 1, September 12, 1935, No. 1, September 29, 1935, No. 1, December 10, 1935, No. 5; December 11, 1935, No. 1, December 11, 1935, No. 2, December 11, 1935, No. 3, December 9, 1935, No. 1, December 13, 1935, No. 4, December 14, 1935, No. 3, January 4, 1936, No. 1, February 15, 1936, No. 5, February 19, 1936, No. 1; Isabela, August 19, 1935, No. 1; Rincón, August 26, 1935, No. 2; Fajardo, Novem- 
ber 13, 1935, No. 5; San Juan, November 12, 1935, No. 5, December 19, 1935, No. 1, October 1, 1926 (WAH) ; Cataño, December 19, 1935, No. 5; Maricao, January 6, 1936, No. 1, April 14, 1936, No. 1; Adjuntas, January 6, 1936, No. 4; Jayuya, January 6, 1936, No. 4; Hormigueros, April 3, 1936, No. 2; Guayanilla, April 6, 1936, No. 2; Sabana Grande, April 6, 1936, No. 4; Añasco, April 7, 1936, No. 4; Ponce, April 13, 1936, No. 4.

26. Megarhinus (Hegarhinus) portoricensis Roeder.

The larva of this species was the largest of any taken in Puerto Rico. Its habitat is restricted to tree holes in association with Aedes mediovittatus and in leaf bases of bromeliads in association with Culcx amoricanus and Wyeomyia mitchellii. It is a preclator on other mosquito larvae and, if necessary, camnibalistic. Its restricted habitat does not allow its predacious habit to be of any significance in the general Puerto Rican mosquito problem.

A single male was taken by M. R. Smith in a coffee grove in Mayagitez during midday on September 18, 1935.

Distribution Records: Mayagïez, September 18, 1935, No. 1. December 10, 1935, No. 1.

\section{Uranotaenia sapphinina (Osten-Sacken).}

Although Uranotacnia larvae are very common in all parts of the coastal plain of Prerto Rico, the two common species cannot be readily separated on larval characters. On the basis of rearings and light-trap collections it appears that this species is present only in small numbers.

The adults do not attack man.

Distribution Records: Cabo Rojo, November 18, 1935, No. 1, Nayagüez, November 8, 1935.

\section{Uranotacnia lowii Theobald.}

This species appeared with regularity and in greater numbers than $U$. sapplirina both in light-trap collections and in reared material during the year. The larvae of this group prefer the water containing much vegetation. They are found in considerable numbers in almost all open-country situations. In one or two cases they were taken in brackish water pools.

As far as known the adults do not attack man or animals.

Distribution Records: Mayagüez, August 22, 1935, No. 1, September 18, 1935, No. 2, October 1, 1935, No. 1, October 8, 1935, No. 3 , November 26, 1935, No. 1; Guánica, October 9, 1935, No. 5, October 9,1935 , No. 8; Rincón, October 10, 1935, No. 5; Lake Cartagena, November 11, 1935, No. 4. 


\section{Anopheles (Nyssorhynchus) albimanus Wiedemann.}

This species is the most abundant of the Puerto Rican anophelines. It is found in all parts of Puerto Rico, yet the most suitable conditions for its development are found in the coastal plain.

The larvae are commonly found in roadside, irrigation (fig. 3), or drainage ditches, in overnight reservoirs (fig. 5), in swamps, and along the margins of streams, rivers, ponds, (fig. 4) and lakes. They also have been found in street gutters, tin cans, and water barrels, but the indications are that they prefer situations in open country. They appear to breed with equal ease in brackish and in fresh water, as they were taken in water having 950 parts of chlorine per 100,000 parts of water.

The adults are active only at night and as many as 1,000 were taken in one horse trap in one night. During the day they remain in hiding and consequently little is known of their diurnal activities. In a few cases the females were recovered by sweeping and in one case a female was taken from the mouth of a crab hole.

Its importance as a carrier of the causative organism of malaria cannot be over-estimated.

Distribution Records: Mayagüez, July 8, 1935, No. 2, July 10, 1935, No. 3, July 31, 1935, No. 1, August 14, 1935, No. 1, August 21, 1935, No. 2, August 22, 1935, No. 1, September 11, 1935, No. 1, September 17, 1935, No. 1, September 29, 1935, No. 1, October 4, 1935, No. 1, October 7, 1935, No. 1 . October 8, 1935, No. 1, November 7, 1935, No. 4, November 26, 1935, No. 1, November 27, 1935, No. 3, November 29, 1935, No. 1, December 10, 1935 No. 3, December 13, 1935, No. 1, January 8, 1936, No. 2, January 10, 1936, No. 1, February 15, 1936, No. 5, March 15, 1936, No. 1, March 16, 1936, No. 3 ; Rincón, August 20, 1935, No. 4; Hormigueros, August 16, 1935, No. 1, September 17, 1935, No. 2; Isabela, August 19, 1935, No. 3; Añasco, August 20, 1935, No. 4, September 19, 1935, No. 1; Pueblo Viejo, August 31, 1935, No. 3, December 18, 1935, No. 1; Río Piedras, August 31, 1935, No. 4; Dorado, September 1, 1935, No. 1; Toa Alta, September 1, 1935, No. 5; Vega Baja, September 2, 1935, No. 1; November 12, 1935, No. 3; Manatí, September 2, 1935, No. 2; Barceloneta, September 2, 1935 No. 3; Ponce, October 3, 1935, No. 2; Guánica, October 9, 1935, No. 5, October 25, 1935, No. 1; January 23, 1936, No. 1; Ensenada, October 17, 1935, No. 1; Aguada, October 10, 1935, No. 3; Guánica, October 25, 1935, No. 1; Aguirre, October 30, 1936, No. 3; October 31, 1935, No. 1; Guayama, October 31, 1935, No. 4; Arroyo, October 31, 1935, No. 5; Salinas, October 31, 1935, No. 6; Quebradillas, November 8, 1935, 
No. 1; Hatillo, November 11, 1935, No. 1; Boquerón, November 11, 1935, No. 1; Lake Cartagena, November 11, 1935, No. 4; Arecibo, November 12, 1936, No. 1; Manatí, November 12, 1935, No. 2; Bayamón, November 12, 1935, No. 4; December 18, 1935, No. 2; San Juan, November 12, 1935, No. 6; Carolina, November 13, 1935, No. 1; Río Grande, November 13, 1935, No. 2; Mameyes, November 13, 1935, No. 3; Luquillo, November 13, 1935, No. 4; Fajardo, November 13, 1935, No. 6; Ceiba, November 13, 1935, No. 7; Naguabo, November 13, 1935, No. 8; Humacao, November 13, 1935, No. 9; Yabucoa, November 13, 1935, No. 10; Maunabo, November 7, 1935, No. 4; Cataño, December 19, 1935, No. 3 ; Adjuntas, January 6, 1936, No. 3; Las Marías, January 17, 1935, No. 2.

\section{Anopheles (Anopheles) crucians (Wiedemann).}

This species is represented by a single larva taken in brackish water in a hoof print at Lake Guánica. This constitutes the first record of the species in Puerto Rico.

Distribution Record: Guánica, January 23, 1935, No. 2.

\section{Anopheles (Anopheles) grabhamii Theobald.}

In so far as abundance in Puerto Rico is concerned this species ranks second among the anophelines. The larvae are found in fresh and in slightly brackish water in habitats similar to those in which larvae of $A$. albimanus are found.

The adults were taken in horse traps and occasionally in light trap and net collections.

Distribution Decords: Dorado, September, 1935, No. 3; Mayagüez, December 10, 1935, No. 4.

32. Anopheles (Anopheles) vestitipennis Dyar \& Knab.

The larvae of this species were not taken, but adults were present in various horse-trap collections. In abundance it ranks third among the anophelines.

Distribution Records: Mayagüez, September 17, 1935, HT, October 15, 1935, HT; Cabo Rojo, December 16, 1935, HT, January 4, 1936, НT.

\section{Corethrella appendiculata Grabham.}

The larva of this species, although small in size, is an effective predator on first-and second-stage Culex larvae. It is found in many open-country habitats having clean water, in crab holes, and in large numbers in the leaf bases of bromeliads.

It probably is of little value in reducing the numbers of mosquitoes attacking man. 
Distribution Records: Mayagüez, August 1, 1935, No. 3, August 21, 1935, No. 3, September 9, 1935, No. 1, September 18, 1935, No. 1, November 27, 1935, No. 1; Maricao, August 25, 1935, No. 1, October 13, 1935, No. 1, January 28, 1936, No. 10 ; Dorado, September 1, 1935, No. 2.

\section{Chaoborus brasiliensis Theobald.}

Adults of this species were taken in large numbers from lighttrap collections, yet the larvae were encountered in only one instance. The larvae were taken in a pool formed by a spring in heavily shaded woøds. Other larvae in the pool were Culex secutor and $C$. inhibitator. Although the larva is predacious it probably does not materially aid in reducing the number of mosquitoes attacking man.

The records below are the first for the West Indies.

Distribution Records: Mayagüez, September 10, 1935, LT, February 15, 1936.

\section{A Key to the Species of Mosquitoes ${ }^{5}$ Occurring in Puerto Rico}

\section{TABLE OF GENERA}

\section{AETITS}

1. Base of hind coxa in line with upper margin of lateral metasternal sclerite

Base of hind coxa distinctly below upper margin of lateral metasternal sclerite

2. Tuft of setae present on metanotum

Setae absent on metanotum Wyeomyia

3. Scutellum crescent shaped Megarhinus

Scutellum trilobed Anopheles

4. Anal vein extending beyond fork of cubitus

Anal vein ending opposite or at base of cubital fork

5. Postspiracular setae present Uranotaenia Postspiracular setae absent__- 8

6. Spiracular setae present_____- Psorophora Spiracular setae absent_-_-_-_- 7

7. Wing scales narrow_-_- Aedes Wing scales broad Mansonia

8. Antennae longer than proboscis________- Deinocerites Antennae not longer than proboseis. Culex

\section{LARVAE}

1. Eighth segment of abdomen provided with a distinct elongate dorsal siphon or respiratory tube.

Eighth segment without a distinct elongate dorsal siphon

2. Anal segment without ventral brush

Anal segment with ventral brush

\footnotetext{
${ }^{5}$ Only the Culicinae or biting mosquitoes are considered.
} 
3. Eighth segment laterally without pecten, having a plate with two coarse setae

Eighth segment laterally with pecten consisting of small teeth...--.--_-_ 4

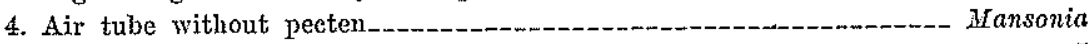

Air tube with pecten

5. Air tube with several pairs of ventral tufts-_-_-_-_._- Culex

Air tuve with a single pair of tufts._........ 6

6. Head elongate, elliptical

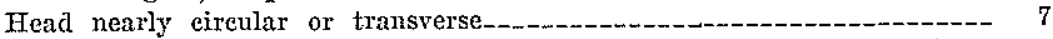

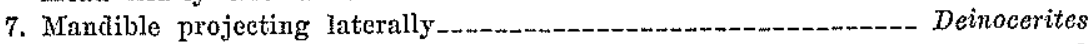

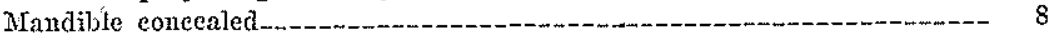

8. Anal segment ringed by dorsal plate with hair tufts piereing ring-- Psorophora Anal segment not ringed by plate, or if ringed the hair tufts posterior

to the ring-_-_.-. Aedes

\section{TABLE OF SPECIES OF PSOROPHORA}

\section{ADUriss}

1. Femora and tibiae distinctly white speckled, first tarsal segment with a

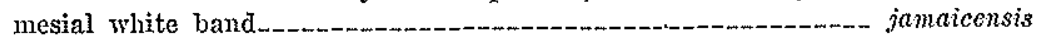

Femora and tibiae scarcely white speckled, first tarsal segment without mesial white band pygmaea

LARVAE

1. Head hairs single pygmaea Head hairs multiple jamaicensis

\section{TABLE OF SPECIES ON AEDES}

ADULTS

1. Tarsi not white marked_._.....- 2

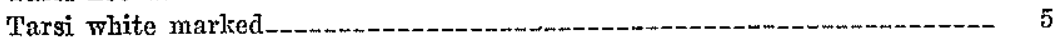

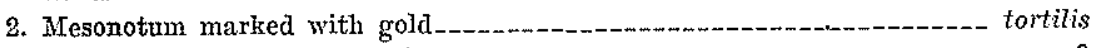

Mesonotum marked with silver-_...- 3

3. Silver on mesonotum in a broad stripe not reaching scutellum_-_._...- 4 Silver on mesonotum in a broad or narrow line reaching scutellum_... mubilus

4. Abdomen with a median whitish-brown longitudinal band--_-_-_---- scapularis

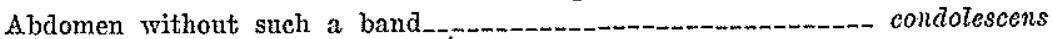

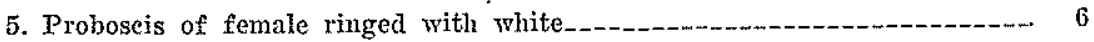
Proboscis of female not ringed with white

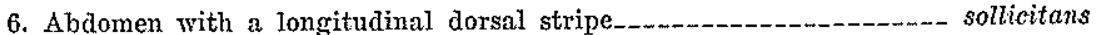
Abdomen without a longitudinal dorsal stripe_-_-_-_._-_-_-_- tacniorhynchus

7. Mesonotum dark with lyre-shaped silvery markings_-_...-_._..._-__..- aegypti Mesonotum light with tliree central narrow silvery lines_._-_.... mediovittatus

LARVAE

1. Anal segment ringed by plate-_- 3

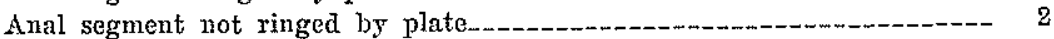

2. Brush of anal segment with a more or less well developed triangular chitinous plate mediovittatus Without this structure. aegypti 
3. Air tube with tuft within pecten

Air tube with tuft beyond pecten

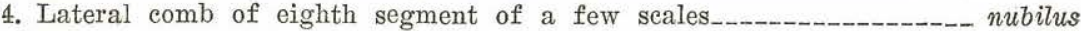
Lateral comb of eighth segment of many scales in a triangular plate_-_ tortilis

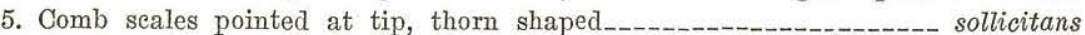
Comb scales with feathered tips__. 6

6. Anal segment short, gills budlike-_-___-_-_-_-_-_-_-_-_oniorhynchus

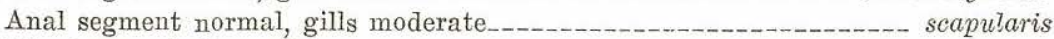
The larva of $A$. condolescens is unknown.

Table of Species of Mansonia

\section{ADULTS}

1. Large reddish forms with palpi over one-third as long as proboscis titillans

Small black and white forms with palpi not as long as one third of proboscis indubitans

\section{LARVAE}

1. Antenna stout with a terminal digit drawn out but distinctly smaller than the antenna itself titillans

Antenna slender with a terminal digit of the same size as antenna and continuous with it indubitans

\section{TABle of Species of Uranotaenia}

ADULTS

1. Tarsi all darky colored sapphirina

Tarsi marked with white lowii

\section{LARVA $\mathrm{E}^{\circ}$}

1. Anal gills pointed sapphirina Anal gills blunt lowii

\section{Table of Species of Culex}

\section{ADULTS}

1. Vertex of head with narrow curved seales

Vertex of head often with small flat seales or many erect forked scales, generally with the tarsi unmarked

2. Tarsal joints white marked

Tarsal joint black

3. Proboscis of female with a distinct central white ring

Proboseis of female without a distinct white ring

4. Proboscis of female with a broad pale area beneath, which may be continued on the upper side as a very narrow ring at about the outer third

habilitator

Proboscis entirely black

5. Abdomen with basal segmental white bands widening on the sides some specimens of nigripalpus

Abdomen without basal segmental bands

${ }^{6}$ Final determination of the species in this genus must depend upon an examination of the adult. 
6. Femora whitish below basally, occiput without erect black bristles_-_-_ secutor Femora entirely whistish below, occuput with erect black bristles_--- janitor

7. Mesonotum with narrow curved scales quinquefasciatus Menosotum with fine hair-like scales_ nigripalpus

8. Palpi over one-third the length of proboseis americanus Palpi less than one-third the length of proboscis pilosus, inhibitator, carcinophitus, atratus

\section{LARVAE}

1. Lateral comb of eighth segment consisting of spines in a single row pilosus

Lateral comb with many seales in a triangular patch.

2. Antennae uniformly shaped, apical portion not more slender-_____-_ 3 Antennae with the apical portion more slender than the basal portion_-- $\quad 4$

3. Abdominal hairs in coarse tufts americamus Abdominal hairs normal, two basal tufts of tube within pecten janitor

4. Anal gills only two bahamensis Anal gill four

5. Air tube with four or more paired tufts, the subapical one moved out of line at outer third of tube

All of the tufts on air tube in line

6. Air tube over five times as long as wide, without marked tapering --_--- 7

Air tube less than five times as long as wide, tapering terminally, subfusiform quinquefasciatus

7. Air tube about eight times as long as wide, with short three-haired tufts

habilitator

Air tube about seven times as long as wide or less, hairs of tube often single nigripalpus

8. Air tube with long well defined tufts

Air tube with small double hair tufts___-_-____________-_ carcinophitus

9. Body spicular pilose_______ 10

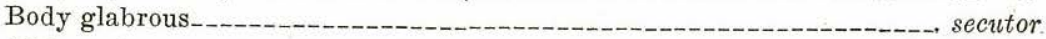

10. Hair tufts on tube all of about the same length_____-__-__-_ atratus

Hair tufts on tube with the basal one long, the rest progressively shorter inhibitator

Culex antillum-magnorum Dyar is not considered to be a valid species but a form of $C$. americanus and, therefore, is not included in this key.

\section{Table to Species of Anopheles}

ADULTS

1. Tarsi marked with white Tarsi dark crucians

2. White markings on hind tarsi different from those of fore and mid tarsi albimanus

White markings on hind tarsi similar to those of fore and and mid tarsi 3

3. Wing scales distinctly inflated grabhamii Wing scales narrow and linear. vestitipennis 
LARVAE

1. Teeth of comb alternatingly long and short Teeth of comb both long and short, irregular. vestitipennis

2. Dorsal float hairs present on abdominal segments $1-7$ albimanus

Dorsal float hairs present on abdominal segments 2-7.

3. Anterior pair of float hairs smaller than others.

Float hairs all equal in size crucians

The following genera are represented by a single species in Puerto Rico:

Wyeomyia, Magarhinus, and Deinocerites.

\section{BibLiography}

(1) Baston, J. Produciendo (breeding) mosquitoes. Rev. Agr. P. R. 20 (5) : 239, 245, 1928.

(2) Dyar, H. F. The mosquitoes of the Americas. Carnegie Institute Pub. No. 387, 616 pp. 418 figs, 1928.

(3) Earle, W. C. Malaria surveys in Porto Rico. P. R. Health Rev. 1 (4) : 12-18, 1925.

(4) The relation of irrigation on cane fields to the malaria problem. Agr. Notes. P. R. (Mayagüez) Agr. Exp. Sta., Office of Farm Management, No. 21, 3 pp., 1 diagram, 1925.

(5) Cane field irrigation and malaria. Sugar $28(8): 384,385,1926$.

(6) Malaria in Porto Rico. Amer. Jour. Trop. Med. 10 (3) : 207-230, 1930. (7) Notes on the life history of Anopheles 7 (3) : 381-384, 1932. (8) Some observations of antimosquito sereenP. R. Jour. Pub. Health and Trop. Med. ing and screening materials. P. R. Jour. Pub. Health and Trop. Med. 8 (2) : 227-234, 1933.

(9) Arbona, Antonio. La malaria en Puerto Rico. Oportunidad que se ofrece a los eañeros como de las mayores entidades que pueden coadyuvar a su restricción. Rev. Agr. P. R. 24 (12) : 235-239, 1930.

(10) Earle, W. C., Palacios, L. D., \& Arbona, A. Methods used to control malaria in Puerto Rico. P. R. Jour. Pub. Health and. Trop. Med. 11 (3) : 434-456, 1936.

(11) Hoffman, W. A., Marín, R. A., \& Burke, A. IM. B. Filariasis in Porto Rico. I. Progress report on general survey. P. R. Rev. Pub. Health and Trop. Med. 4 (3) : 120-127, 1 map, 1928, (Abs. in Rev. Appl. Ent. B. $17: 115,1928$.)

(12) Howard, L. O., Dyar, H. G. \& Knab, F. The mosquitoes of North and Central America and the West Indies. Pub. No. 159, 4 vols. illus. Carnegie Institution of Washington, 1912-1917.

(13) Johnson, H. A. Occurrence of Anopheles vestitipennis in Puerto Rico. American Jour. Trop. Med. 6 (2) : 153-156, 1926.

(14) King, W. W. The epidemic of dengue in Puerto Rico; 1915. New Orleans Med. Surg. Jour. 69 (8) : 564-71. 1917. (Abs. in Rev. Appl. Ent. Ser. B. 5 : 61.) 
(15) Kudo, R. Studies on Microsporidia parasitic in mosquitoes. VIII, on a Microsporidian, Nosema aedis nov. spec., parasitic in a larva of Aëdes aegypti of Puerto Rico. Archiv. Protistenkunde, 69 (1) : 23-38, 2 pls., Jena, 1930. Notice by Title in Rev. Appl. Ent. B $18: 87$.)

(16) McKinley, Earl B. The salivary gland poison of the Aëdes aegypti. Proc. Soc. Exp. Biol. and Med. 26 (9) : 806-809. 1929.

(17) Ortiz, P. N. Report of Bureau of Malaria Control 1926-27. Report Commissioner Health P. R. pp. 62-95, 1929. (Abs. in Rev. Appl. Ent. B 17-218.)

(18) Porto Rico Health Review. Studies of the malaria problem in Puerto Rico., 2 (5) : 22-28 (Abs. in Pub. Health Rpts. 42 (13) : 879.), 1926.

(19) Porto Rico Health Review. Studies of the malaria problem in Puerto Rico., $2(8): 25-32 ; 2$ (10) : 27-32; 2 (12) : 25-31 1927 (Abs. in Rev. Appl. Ent. B 16 p. 64 and in U. S. Pub. Health Repts. 42 (39) : $2395 ; 42(51): 3142$.

(20 Porto Rico Review Pub. Health and Trop. INed. Report of Bureau of malaria control 1926-27. P. R. Rev. Pub. Health and Trop. Med. 3 (7) : 279-286; 3(9) : 376-385, 1928. (Abs. in Rev. Appl. Ent. B 16 : 239 and 209 respectively and the former also in U. S. Pub. Health Repts. 43 (30) : 1992-1993.)

(21) Roeder, Victor Von. Dipteren von der insel Porto Rico, etc. Entomol. Zeit. 337-349. Stettin, 1885.

(22) Root, F. M. Notes on mosquitoes and other blood-sucking flies from Porto Rico. Amer. Jour. Hygiene 2 (4) : 394 405, 1922.

(23) Russell, F. F. Field studies and demonstrations in malaria contro. 11th An. Rept. Intern. Health Bd. Rockefeller Foundation. 1924 pp. 73-84, 1925. (Abs. in Rev. Appl. Ent. B 14 : 51-52.)

(24) Tower, W. V. A study of Mosquitoes in San Juan, Porto Rico. P. R. Agr. Expt. Station. Cir. No. 14, 23 pp. 1912.

(25) Mosquito survey of Mayagüez. Porto Rico Agr. Exp. Sta. Cir. No. 20, 10 pp., illus. 1921.

(26) Wolcott, G. N. Insectae Borinquensis. Jour. Dept. Agr. P. R. Vol. 20, (1) : 1-600, illus. 1936. 


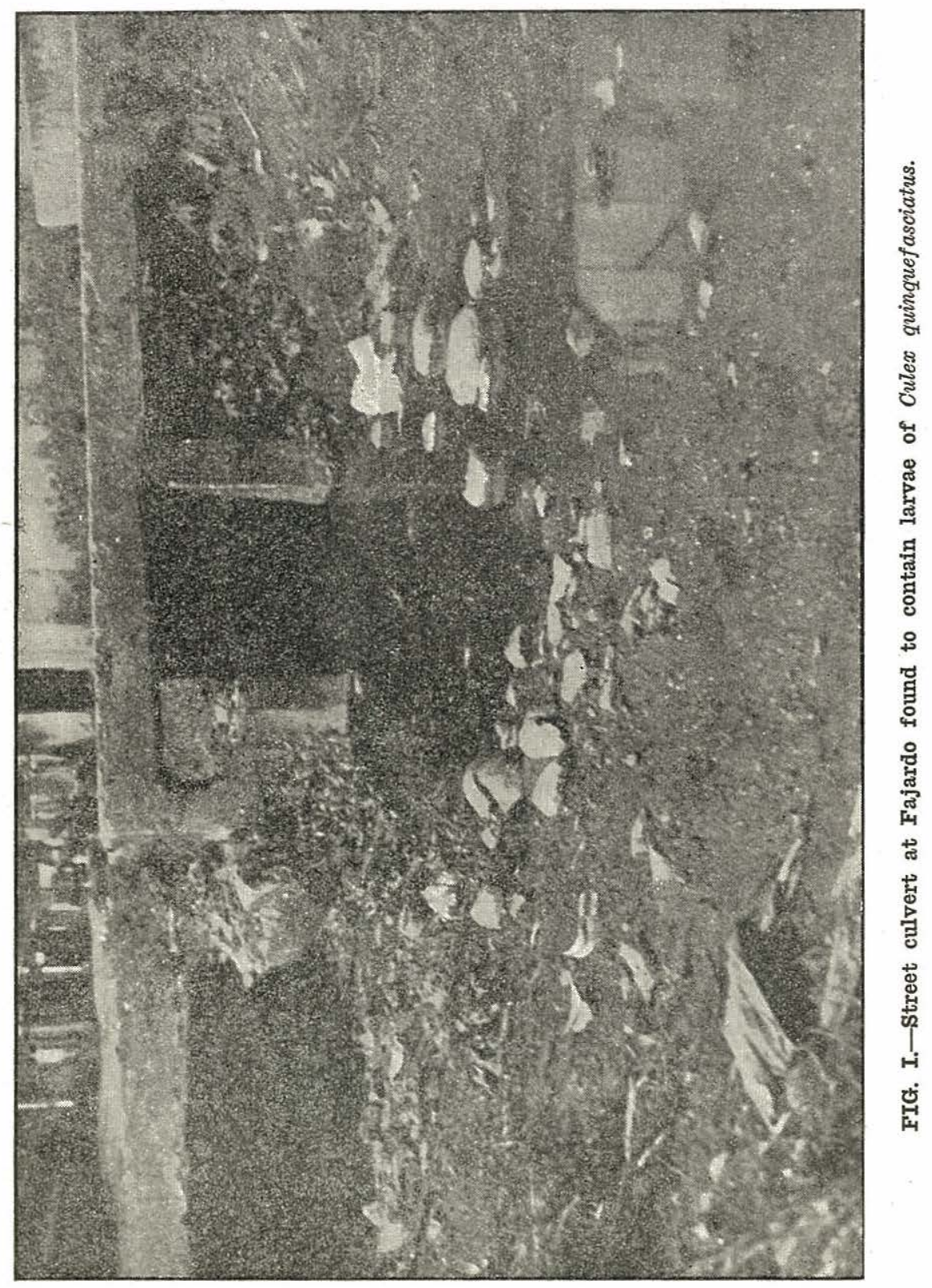




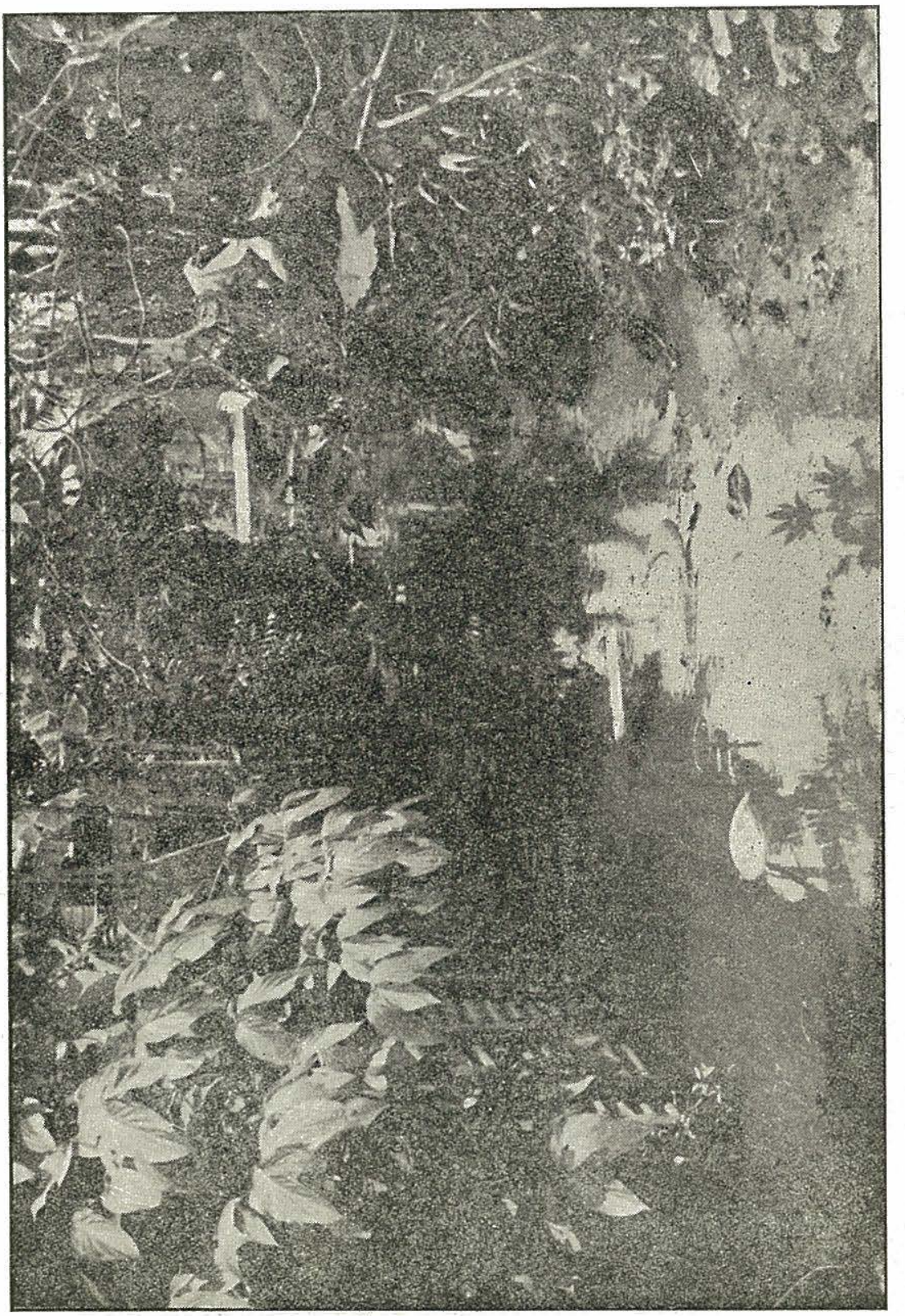

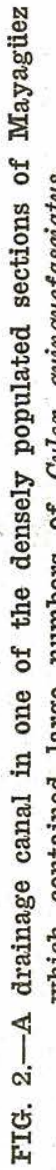




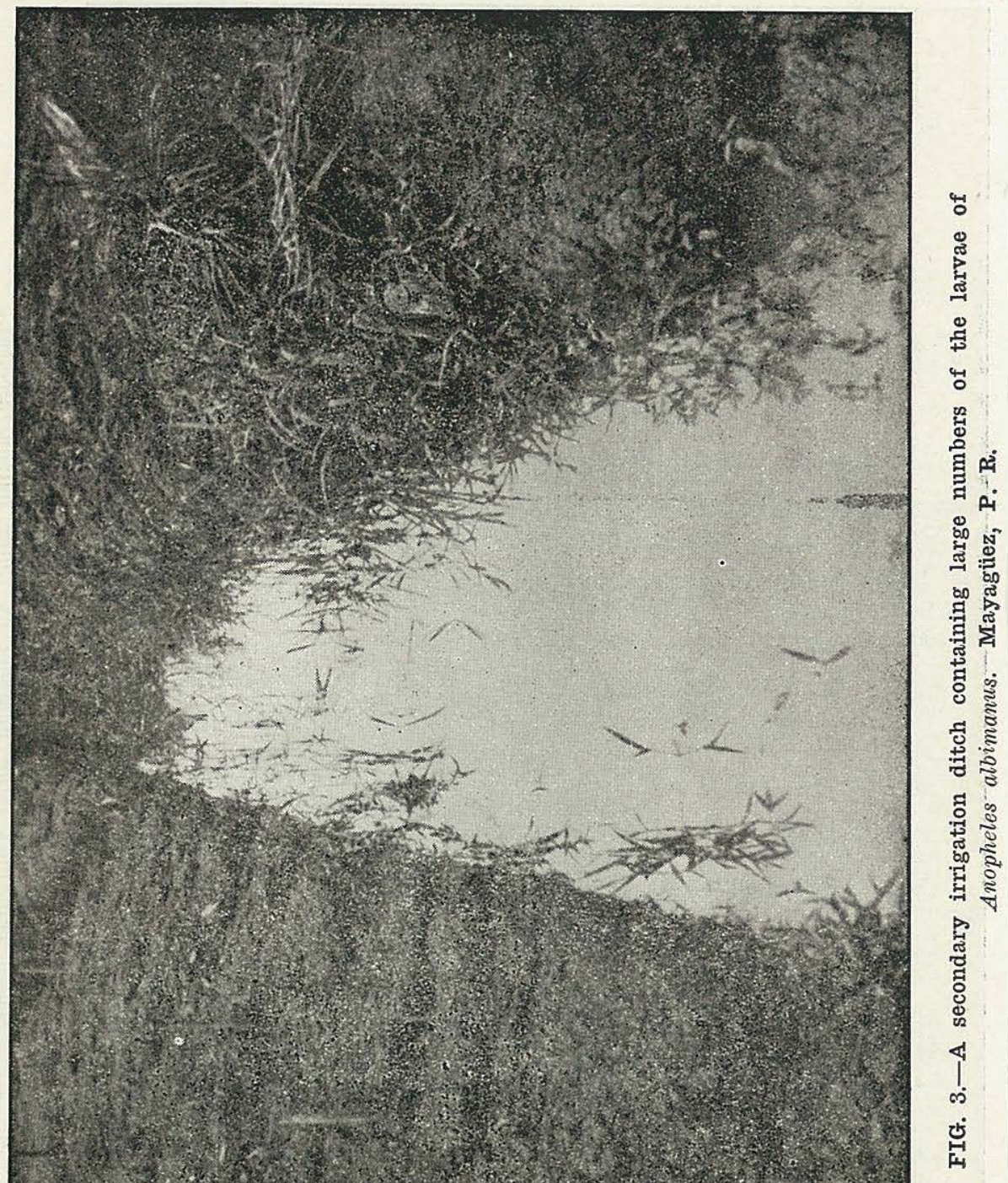




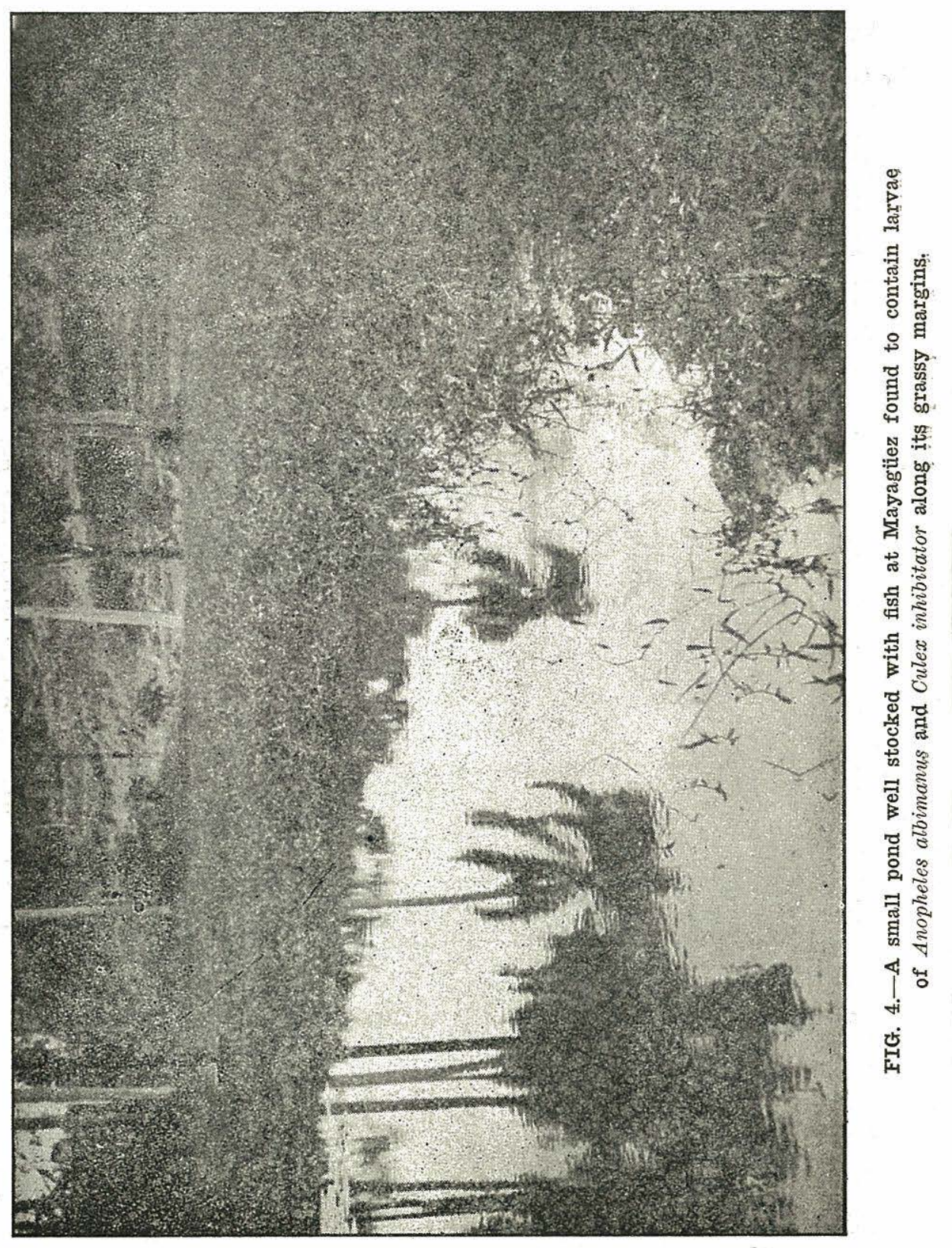




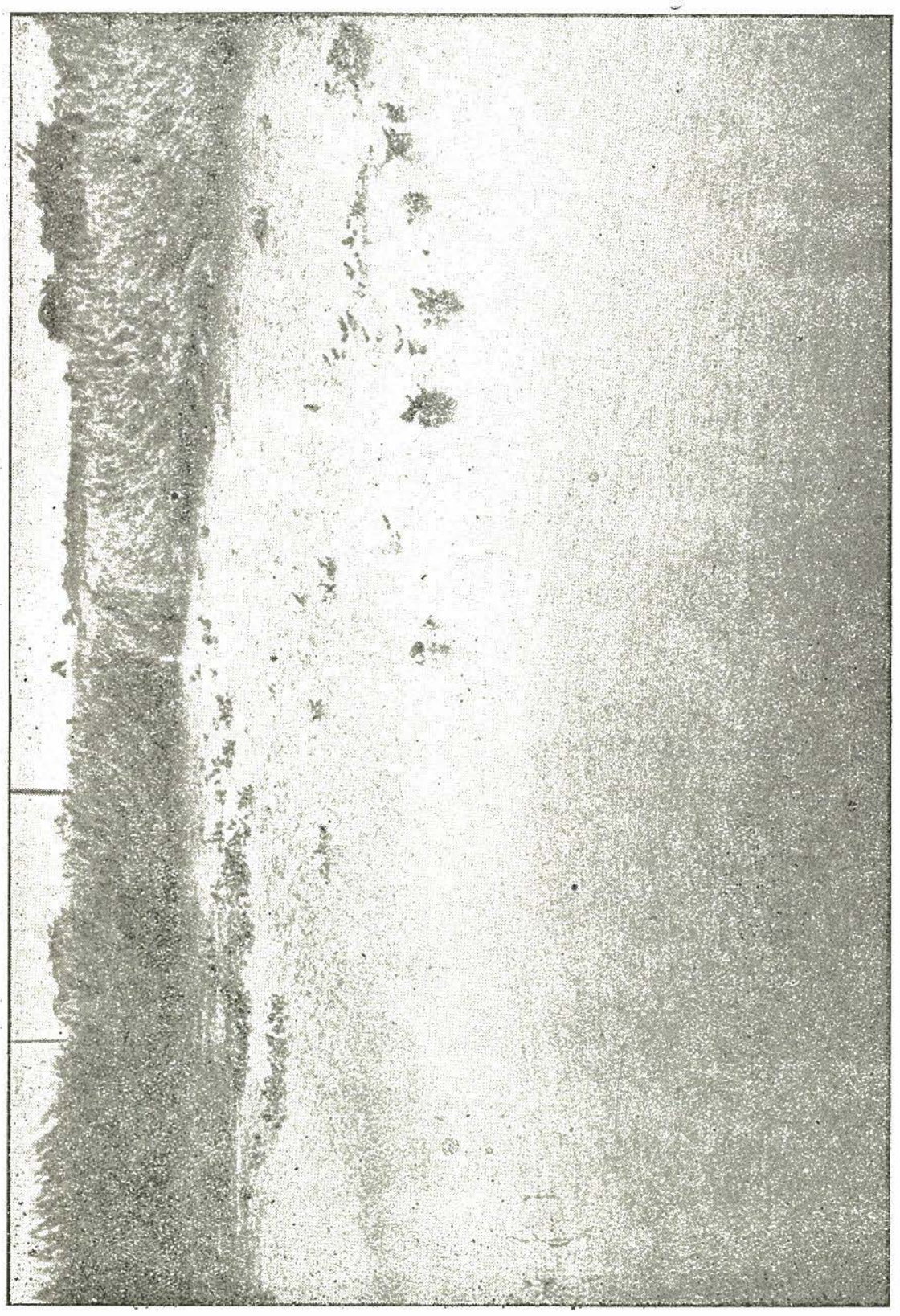




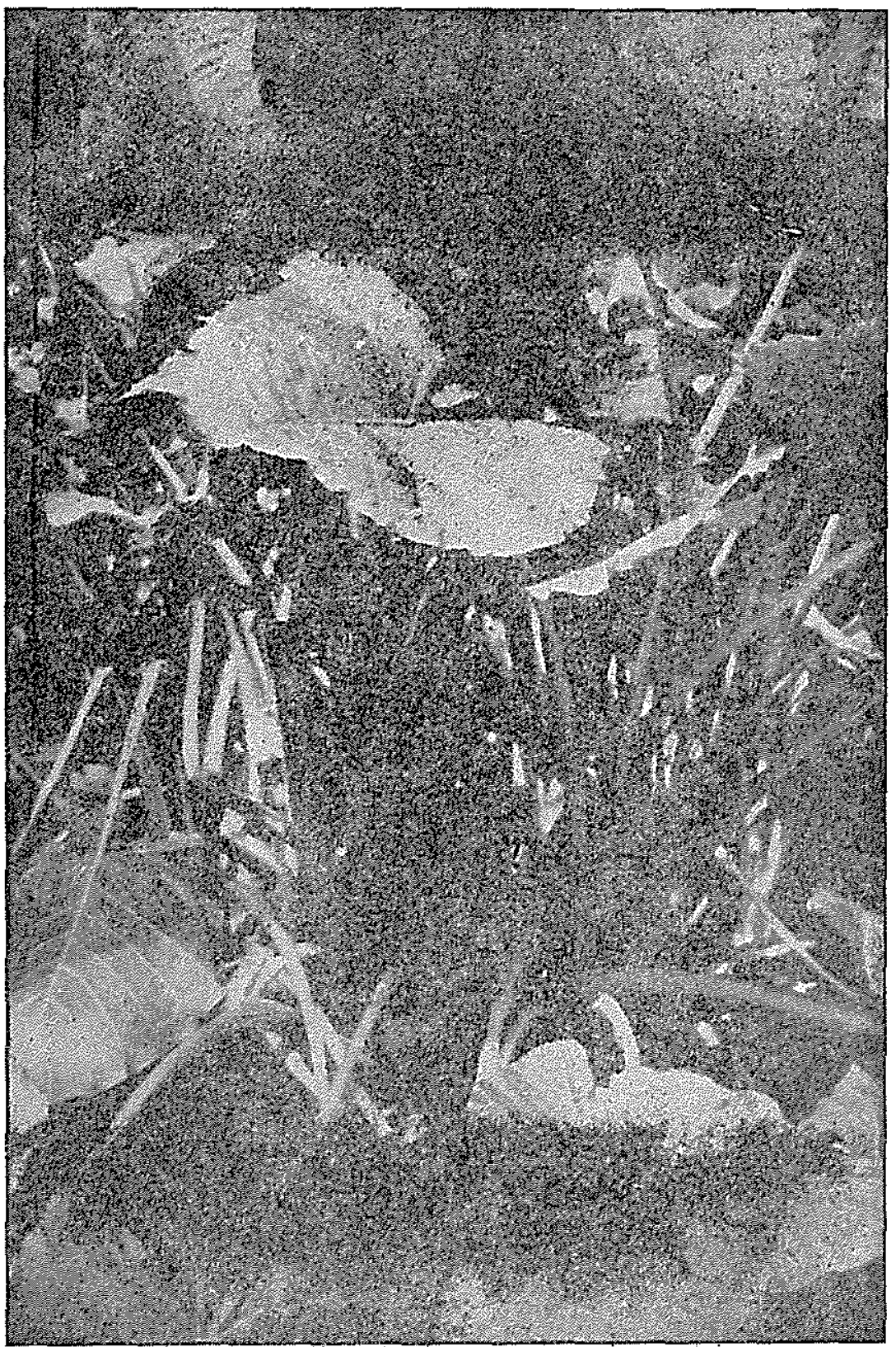

FIG. 6. $\rightarrow$ Iarvae of Culax annericanus were found in the leaf bases of Caladium colocasia, commonly known as "malanga." 


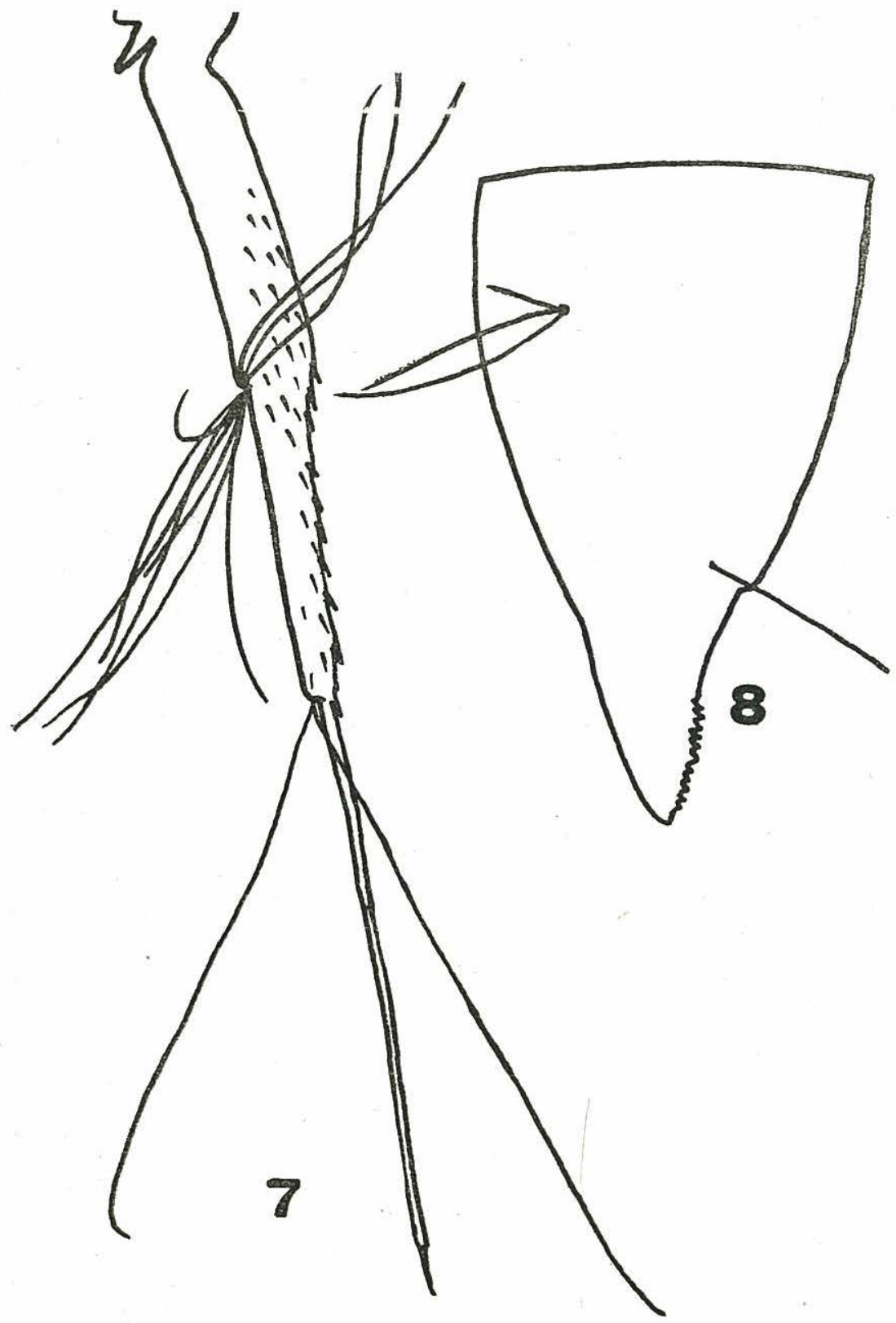

FIG. 7.-Mansonia (Mansonia) indubitans: Antenna of larva. FIG. 8.-Mansonia (Mansonia) indubitans: Air tube of larva. 


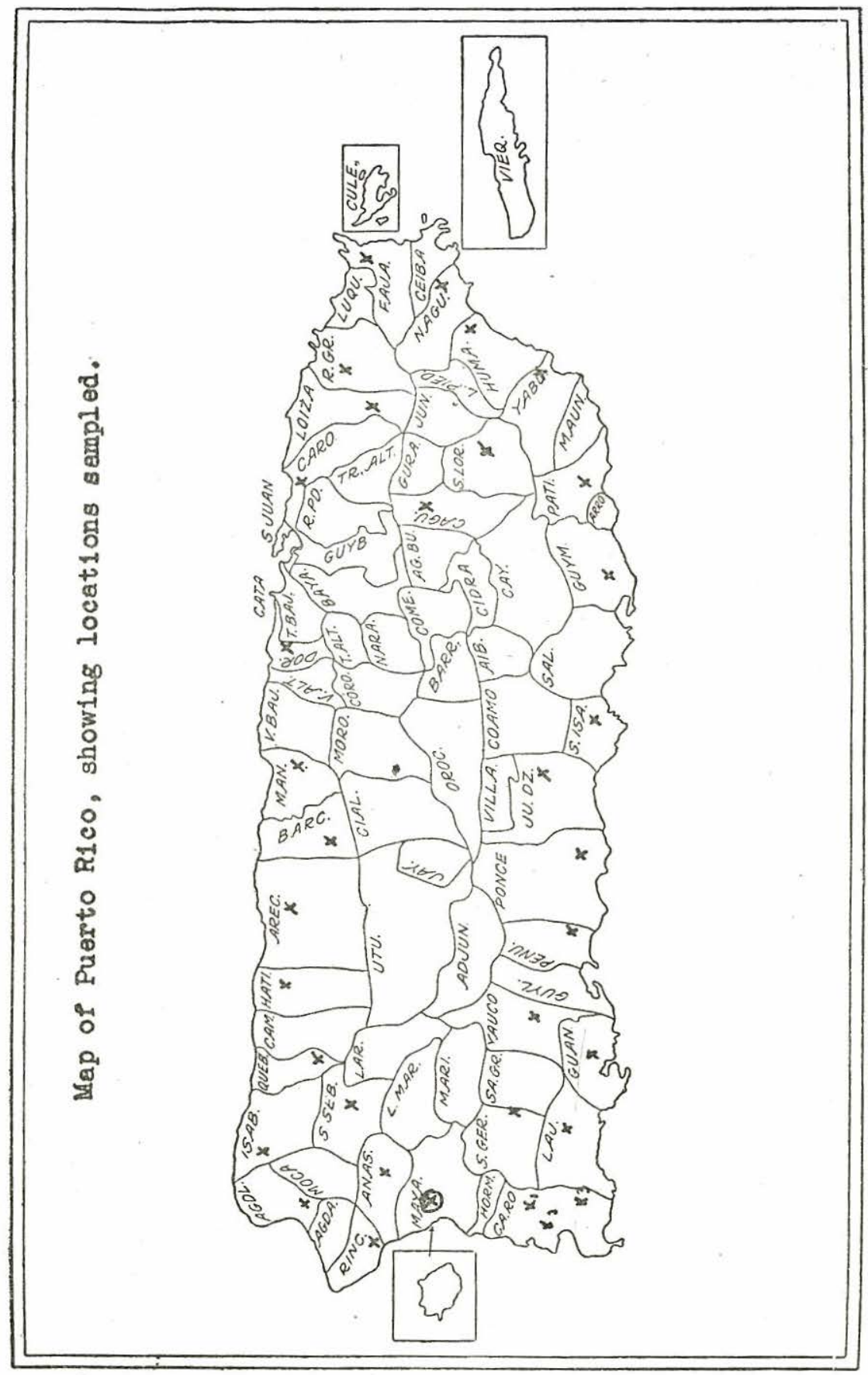

